\title{
A novel and more efficient biosynthesis approach for human insulin production in Escherichia coli (E. coli)
}

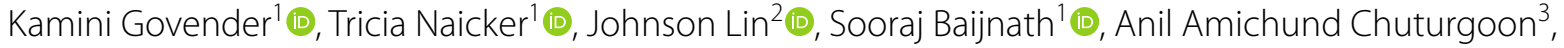 \\ Naeem Sheik Abdul ${ }^{3}$, Taskeen Docrat ${ }^{3}$, Hendrik Gerhardus Kruger ${ }^{r^{* *}}$ (D) and Thavendran Govender ${ }^{4^{*}}$ (D)
}

\begin{abstract}
Insulin has captured researchers'attention worldwide. There is a rapid global rise in the number of diabetic patients, which increases the demand for insulin. Current methods of insulin production are expensive and time-consuming. A PCR-based strategy was employed for the cloning and verification of human insulin. The human insulin protein was then overexpressed in E. coli on a laboratory scale. Thereafter, optimisation of human insulin expression was conducted. The yield of human insulin produced was approximately 520.92 (mg/L), located in the intracellular fraction. Human insulin was detected using the MALDI-TOF-MS and LC-MS methods. The crude biosynthesised protein sequence was verified using protein sequencing, which had a 100\% similarity to the human insulin sequence. The biological activity of human insulin was tested in vitro using a MTT assay, which revealed that the crude biosynthesised human insulin displayed a similar degree of efficacy to the standard human insulin. This study eliminated the use of affinity tags since an untagged pET21b expression vector was employed. Tedious protein renaturation, inclusion body recovery steps, and the expensive enzymatic cleavage of the C-peptide of insulin were eliminated, thereby making this method of biosynthesising human insulin a novel and more efficient method.
\end{abstract}

Keywords: Biosynthesis of human insulin, Diabetes, E. coli

\section{Introduction}

In 2018, it was estimated that 405.6 million people suffered from Type 2 diabetes, and this number is projected to increase to approximately 510.8 million by the year 2030. Based on these estimates, the global usage of insulin is estimated to rise from 516.1 million vials (1000 IU) to 633.7 million vials in 2030 (Basu et al. 2019). The increase in diabetic patients, coupled with the development of oral and inhalation methods of insulin delivery, requires considerable amounts of insulin. The current

\footnotetext{
*Correspondence: kruger@ukzn.ac.za; govendert@unizulu.ac.za

${ }^{1}$ Catalysis and Peptide Research Unit (CPRU), School of Health Sciences, University of KwaZulu-Natal, E-block, 6th Floor, Room E1-06-016, Westville Campus, Durban, South Africa

${ }^{4}$ Department of Chemistry, University of Zululand, Private Bag X1001,

Kwadlangezwa 3886, South Africa

Full list of author information is available at the end of the article
}

producers of insulin would not be able to cope with the rapid demand of affordable insulin as a result of high production costs and production capacity limitations (Baeshen et al. 2014).

Insulin has an essential role in glucose homeostasis (Ahmad 2004). It is produced by the beta cells of the pancreas and is one of the main anabolic hormones in the human body (Voet and Voet 2011). It is synthesised by beta cells in the pancreas and has a fundamental role in fat and carbohydrate metabolism (Ahmad 2004). Human insulin is a 51 amino acid (aa) polypeptide. It contains two polypeptide chains. The A chain has 21 amino acids and the $\mathrm{B}$ chain contains 30 amino acids. Insulin has three disulfide bonds. Two of the disulfide bonds interlink the $\mathrm{A}$ and $\mathrm{B}$ chains, whereas the third one is an intra A chain bond (Ahmad 2004; Vajo et al. 2001). Insulin was first discovered in 1921 by Charles Best and Frederick
Springer Open (c) The Author(s) 2020. This article is licensed under a Creative Commons Attribution 4.0 International License, which permits use, sharing, adaptation, distribution and reproduction in any medium or format, as long as you give appropriate credit to the original author(s) and the source, provide a link to the Creative Commons licence, and indicate if changes were made. The images or other third party material in this article are included in the article's Creative Commons licence, unless indicated otherwise in a credit line to the material. If material is not included in the article's Creative Commons licence and your intended use is not permitted by statutory regulation or exceeds the permitted use, you will need to obtain permission directly from the copyright holder. To view a copy of this licence, visit http://creativeco mmons.org/licenses/by/4.0/. 
Banting (Banting and Best 1922). Prior to 1982, insulin was extracted from the pancreas of animals such as bovines and porcine (Beals et al. 2013; Mollerup et al. 2009).

The biotechnological industry can, possibly, develop suitable innovations to curb the shortage in the supply of human insulin. Novel innovations in methods of insulin production and purification have the potential to significantly advance the pharmaceutical biotechnology industry. The use of recombinant deoxyribonucleic acid (DNA) technology allowed for a direct method of biosynthesising human insulin, which did not require animal-derived pancreatic tissue (Walsh 2005). In 1982, Novo Nordisk derived semi-synthetic human insulin, whereby porcine insulin was converted into human insulin enzymatically. Human insulin was biosynthesised by Eli Lilly using recombinant DNA technology in 1982. Two production methods were reported by Eli Lilly (Mollerup et al. 2009). The first method consisted of cloning the A and B chains of insulin separately in E. coli; thereafter, these two chains were isolated, purified, and chemically attached. Subsequently, the final reversed phase-high performance liquid chromatography (RP-HPLC) purification steps were conducted (Chance et al. 1981; Frank and Chance 1983; Mollerup et al. 2009). The second method of cloning recombinant insulin in E. coli consisted of the expression of proinsulin under a tryptophan promoter that had a methionine bond to proinsulin. This study cloned the A and B chains of human insulin together in E. coli. In 1988 Novo Nordisk launched the biosynthesis of human insulin using recombinant DNA technology (Mollerup et al. 2009). The proinsulin biosynthesis strategy of human insulin is the preferred method. However, this procedure results in the formation of inclusion bodies and requires the use of enzymes such as carboxypeptidase B to remove the C-peptide (Redwan et al. 2007; Zieliński et al. 2019) and the use of affinity tags (Redwan et al. 2007). The inclusion body formation requires additional steps to be taken, such as the renaturation of the protein (Redwan et al. 2007; Zieliński et al. 2019). This study aimed to create a novel and more efficient method for the biosynthesis of human insulin employing a polymerase chain reaction (PCR)-based strategy using the pET21b expression vector in $E$. coli for the optimisation of human insulin expression.

\section{Materials and methods \\ Bacterial strains}

The bacterial strains employed in this study were obtained from the School of Life Sciences, in the Discipline of Microbiology (University of KwaZulu-Natal, Westville Campus, South Africa). The pCMV6-XL5 plasmid integrated with the gene encoding for human proinsulin was procured from ORI Gene (United States of America (USA). Commercial human insulin protein was obtained from Sigma-Aldrich Inc (Germany) as a control in this study. All restriction enzymes were purchased from Thermo-Scientific, USA.

\section{Cloning of human insulin in E. coli}

An amplification of human insulin was conducted using a PCR master mix according to the manufacturer's instructions (Thermo-Scientific, USA). The pCMV6-XL5 plasmid was used as a DNA template with the following primers: (PGEX-BamHI-F: $5^{\prime}$-GGA TCC ATG GCC CTG TGG ATG CG-3' and PGEX-XhoI-R: 5' $^{\prime}$ CTC GAG CTA GTT GCA GTA GTT CTC C-3). The PCR conditions were as follows: a denaturation at $95^{\circ} \mathrm{C}$ for $30 \mathrm{~s}$, followed by an annealing step at $61.2^{\circ} \mathrm{C}$ for $30 \mathrm{~s}$; thereafter an elongation step at $72{ }^{\circ} \mathrm{C}$ for $1 \mathrm{~min}$, and lastly another elongation at $72{ }^{\circ} \mathrm{C}$ for $2 \mathrm{~min}$. The PCR comprised 30 cycles. The PCR amplicons were subsequently visualised on a 1.5\% agarose gel (Helling et al. 1974) and viewed using a Syngene G BOX gel documentation system (Vacutec, South Africa). The respective band was cut off using a scalpel under a UV trans-illuminator (UVP incorporated, USA). PCR products were then purified using the Zymoclean ${ }^{\mathrm{TM}}$ gel DNA recovery kit (ZYMO Research, USA), following the manufacturer's instructions.

The pET21b vector DNA was isolated using a Zyppy $^{\mathrm{TM}}{ }^{\mathrm{T}}$ kit (ZYMO Research, USA), as per the manufacturer's instructions. Thereafter, the PCR amplicons and the pET21b vector were digested with BamHI and XhoI, according to the manufacturer's instructions (ThermoScientific, USA). Thereafter, the restricted PCR products were inserted into the pET21b vector using T4 DNA ligase (Thermo-Scientific, USA), according to the manufacturer's instructions. The pET21b vector human proinsulin (designated as pET21b-hPin) was transformed in chemically competent E. coli BL21 (DE3) cells plasmid using the calcium chloride heat shock method (Inoue et al. 1990).

\section{The expression and isolation of the protein}

The transformed E. coli BL21 (DE3) (Thermo-Scientific, USA) was verified using colony PCR. The positive clones were incubated in $10 \mathrm{~mL}$ of Luria-Bertani (LB) medium ( $1 \%$ bacto tryptone, $0.5 \%$ yeast extract, $1 \% \mathrm{NaCl}$ ) containing $50 \mu \mathrm{g} / \mathrm{mL}$ ampicillin and $34 \mu \mathrm{g} / \mathrm{mL}$ chloramphenicol (Merck, Germany) overnight at $37^{\circ} \mathrm{C}$ at 180 revs per minute (rpm). One millilitre of an overnight culture was used to inoculate $100 \mathrm{~mL}$ of LB broth using the above method (Maseko et al. 2016; Volontè et al. 2011). The expression of human proinsulin was induced by the addition of 0.1 to $1 \mathrm{mM}$ Isopropyl $\beta$-D thiogalactoside (IPTG) at an early exponential phase $\left(\mathrm{OD}_{600} 0.4-0.7\right)$. 
The over-expressed protein was recovered following to a similar method adapted from Maseko et al. (2016). After overnight induction at $16{ }^{\circ} \mathrm{C}$, the cultures were transferred to $50 \mathrm{~mL}$ Cell Star ${ }^{\circledR}$ centrifuge tubes (Greiner Bio-One, Austria) and spun down at $8000 \mathrm{rpm}$ for $15 \mathrm{~min}$ at $4{ }^{\circ} \mathrm{C}$. The pellet was resuspended in $50 \mathrm{mM}$ Tris- $\mathrm{HCl}$ $(\mathrm{pH}=8)$. The crude protein extracts were sonicated for 5 to $10 \mathrm{~min}$ on ice until the cells were homogenised with a Sonic Ruptor 400 Ultrasonic homogeniser (Omni International, United States of America). Thereafter, the samples were centrifuged at $8000 \mathrm{rpm}$ for approximately $15 \mathrm{~min}$ at $4{ }^{\circ} \mathrm{C}$, and the supernatant was transferred to a clean centrifuge tube and stored at $4{ }^{\circ} \mathrm{C}$. The proinsulin was converted to mature human insulin as a result of the autocatalytic cleavage of the C-peptide (Gooch 2011). Thereafter, the crude protein was concentrated using $3 \mathrm{kDa}$ (kilo-Dalton) Amicon ${ }^{\circledR}$ ultra-size exclusion centrifugal filters (Merck, Germany), according to the manufacturer's instructions.

\section{Detection of human insulin by matrix-assisted laser desorption ionization-time of flight-mass spectrometry (MALDI-TOF-MS)}

The autoflex III smartbeam MALDI-TOF-MS (Bruker Daltonics, Germany) was used for the detection of the standard human insulin and biosynthesised human insulin samples. The MALDI-TOF spectra were obtained from linear mode, where by ions charged at a voltage of 20 kilovolts $(\mathrm{kV})$ within a molecular mass detection range of 1500 to 7000 Daltons (Da) were employed. The instrument contained an ultraviolet nitrogen laser at 337 nanometres (nm). FlexControl version 3.4 build 119 software was used for the data acquisition and FlexAnalysis of the MALDI-TOF spectra. The target that was employed in the study was a ground steel target plate (Bruker Daltonics, Germany). The protein samples were diluted and spotted on the ground steel plate according to the manufacturer's instructions (Bruker Daltonics, Germany). The matrix utilised in this study was alpha-cyano-4-hydroxycinnamic acid (CHCA or HCCA) (Bruker Daltonics, Germany). A standard curve was generated whereby standard human insulin was diluted to the required concentration using the HCCA matrix. The standard curve comprised of $0 \mathrm{ng} / \mathrm{mL}, 10 \mathrm{ng} / \mathrm{mL}, 50 \mathrm{ng} / \mathrm{mL}, 100 \mathrm{ng} /$ $\mathrm{mL}$, and $1000 \mathrm{ng} / \mathrm{mL}$ concentrations (refer to Additional file 1: Figure S4).

\section{Liquid chromatography-mass spectrometry (LC-MS)}

The sample containing human insulin was further confirmed using the LC-MS-2020 (Shimadzu, Japan) with a YMC-Triart C18 column $(150 \mathrm{~mm} \times 4.6 \mathrm{~mm}$ internal diameter, pore size of $120 \AA$ and a particle size of $5 \mu \mathrm{m}$ ) (YMC, Japan), coupled to a NM32LA nitrogen generator
(Peak Scientific Instruments, United Kingdom). The MS spectra were obtained using the positive mode with a mass range of 200 to $1500 \mathrm{~m} / \mathrm{z}$. Mobile phase A was Millipore water (Millipore, USA) and mobile phase B was acetonitrile (Merck, Germany). Both these mobile phases contained $0.1 \%(\mathrm{v} / \mathrm{v})$ formic acid as an ion-pairing agent. Flow rates of $1.0 \mathrm{~mL} / \mathrm{min}$ were used with a total run time of $25 \mathrm{~min}$. The gradient profile was from 5 to $95 \%$ acetonitrile in $7 \mathrm{~min}$; and at $95 \%$ acetonitrile for a further $18 \mathrm{~min}$. The column temperature was maintained at $40{ }^{\circ} \mathrm{C}$. The nebuliser was set at 1.5 bar with a desolvation gas temperature of $250{ }^{\circ} \mathrm{C}$ and dry gas flow rates of $10 \mathrm{~L} /$ $\min$.

\section{Protein sequencing of human insulin}

An in-solution digestion of the protein samples were conducted at the Central Analytical Facility (Stellenbosch University, South Africa) on an Ultimate 3000 RSLC (Thermo Fisher Scientific, USA), coupling with a mass spectrometry (fusion mass spectrometer) (Thermo Fisher Scientific, USA) and an ionisation source (Nanospray Flex). The files generated from the mass spectrometer were imported onto the Proteome Discoverer v1.4. The procedure was conducted according to the manufacturer's instructions (Thermo Fisher Scientific, USA), and analysed using an Amanda algorithm and Sequest. Thereafter, a concatenated database interrogation was conducted using the Uniprot P09211, concatenated with the contaminant protein database (cRAP). The peptides were validated using Target-Decoy PSM validator mode. The results were imported according to the manufacturer's instructions using Scaffold 1.4.4 software (Proteome Software Inc, USA), and the identified peptides were validated with the peptide, Protein Prophet, as well as X!Tandem algorithms from the Scaffold 1.4.4 software (Proteome Software Inc, USA).

\section{Biological activity}

The biological activity of the standard human insulin and the crude biosynthesised human insulin was conducted in vitro using a 3-(4,5-dimethylthiazol-2-yl)-2, 5-diphenyl tetrazolium bromide (MTT) assay. A hepatocellular carcinoma (HepG2) (Highveld Biologicals, South Africa) cell line was used. The HepG2 cells were cultured according to a method similar that reported by Abdul et al. (2016). The cell culture reagents were obtained from Whitehead Scientific (South Africa). The standard human insulin and crude biosynthesised human insulin stocks were made in Eagle's essential minimal medium (EMEM) (catologue number: 12-136F, Lonza, Switzerland) up to a concentration of $1 \mathrm{mg} / \mathrm{mL}$. In the MTT assay, three treatment concentrations were used of the 
standard human insulin and crude biosynthesised human insulin: low $(50 \mu \mathrm{g} / \mathrm{mL})$, medium $(100 \mu \mathrm{g} / \mathrm{mL})$, and high $(150 \mu \mathrm{g} / \mathrm{mL})$.

The HepG2 cells were seeded into a 96-well plate $\left(2 \times 10^{4}\right.$ cells/well, $\left.24 \mathrm{~h}\right)$. Thereafter, the culture medium was removed, and cells were washed with PBS. The HepG2 cells were then treated with standard human insulin and crude biosynthesised human insulin hyperglycaemic $(25 \mathrm{mM})$ media for $15 \mathrm{~min}$ (Chen et al. 2006). The treatments were removed by washing the cells in PBS, and $120 \mu \mathrm{L}$ MTT ( $5 \mathrm{mg} / \mathrm{mL}$, PBS) was added to each well. This was followed by an incubation of $4 \mathrm{~h}$ at $37^{\circ} \mathrm{C}$. The formazan crystals were solubilised by the addition of $100 \mu \mathrm{L} /$ well DMSO. The optical densities (OD) were measured spectrophotometrically (BioTek uQuant, USA) at $570 \mathrm{~nm}$ with a reference wavelength of $690 \mathrm{~nm}$. All experiments were conducted in triplicate.

The following formula was used to calculate cell viability (\%):

$$
\% \text { Cell viability }=\frac{O D \text { of treated cells }}{O D \text { of control cells }} \times 100
$$

\section{Statistical analysis}

Two-way analysis of variance (ANOVA) was conducted. Analyses were performed using the statistical software package Graph pad in stat version 8.1.0 (325) 64 bit for Windows (Graph pad software, San Diego California).

\section{Results}

PCR amplification and purification of human proinsulin replicons

A PCR amplification of human proinsulin was conducted using PCR primers PGEX-BamHI-F and PGEX-XhoI-R. The mass amplified and purified product corresponded to the expected amplicon size of $345 \mathrm{bp}$ (Additional file 1: Figure S1a, lane 2). The human proinsulin replicons were inserted into pET21b. The pET21b-hPin plasmid (Fig. 1) was then transformed successfully into E. coli BL21 (DE3) cells, which were confirmed by colony PCR (345 bp; Additional file 1: Figure S1b).

\section{Detection and optimisation of expression of human insulin using MALDI-TOF-MS}

The expression of human insulin was conducted by expressing the protein at varying IPTG concentrations, such as $0.1 \mathrm{mM}, 0.5 \mathrm{mM}$, and $1 \mathrm{mM}$. The standard human insulin and the crude biosynthesised human insulin were detected using MALDI-TOF-MS, as the expected size of human insulin was obtained (approximately $5.8 \mathrm{kDa}$ ). Figure 2 shows an example of the MALDI-TOF spectrum, illustrating the supernatant sample of crude biosynthesised human insulin, which was induced at $1 \mathrm{mM}$ IPTG. The results were confirmed using commercial human insulin as the sample using MALDI-TOF (Additional file 1: Figure S2) and LC-MS (Additional file 1: Figure S3). The LC-MS spectra detected the $[\mathrm{M}+4 \mathrm{H}]^{4+}$, $[\mathrm{M}+5 \mathrm{H}]^{5+},[\mathrm{M}+6 \mathrm{H}]^{6+}$, and $\left.\mathrm{M}+7 \mathrm{H}\right]^{7+}$ charged states of the human insulin protein in all IPTG induced samples (Additional file 1: Figure S3).

Human insulin was detected in all the intracellular and inclusion body fractions under all IPTG induction

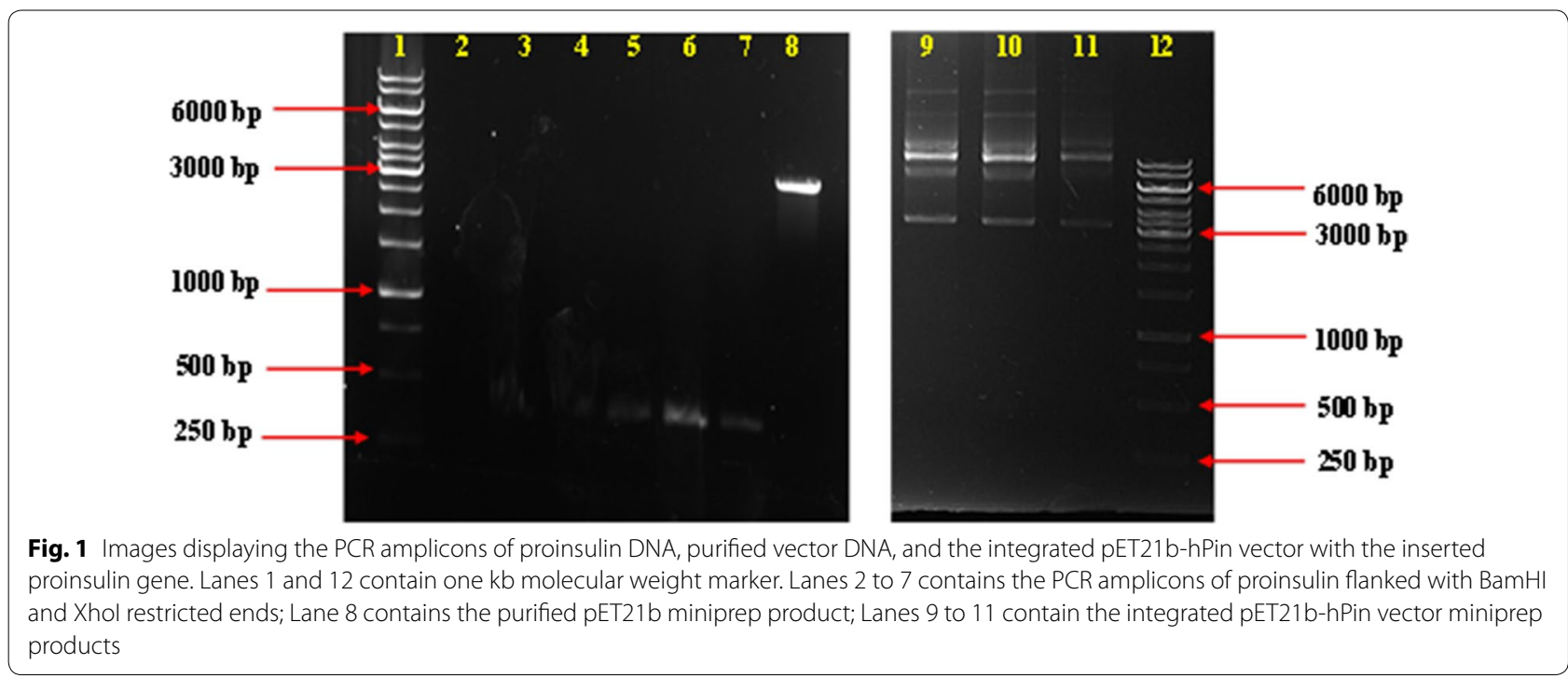




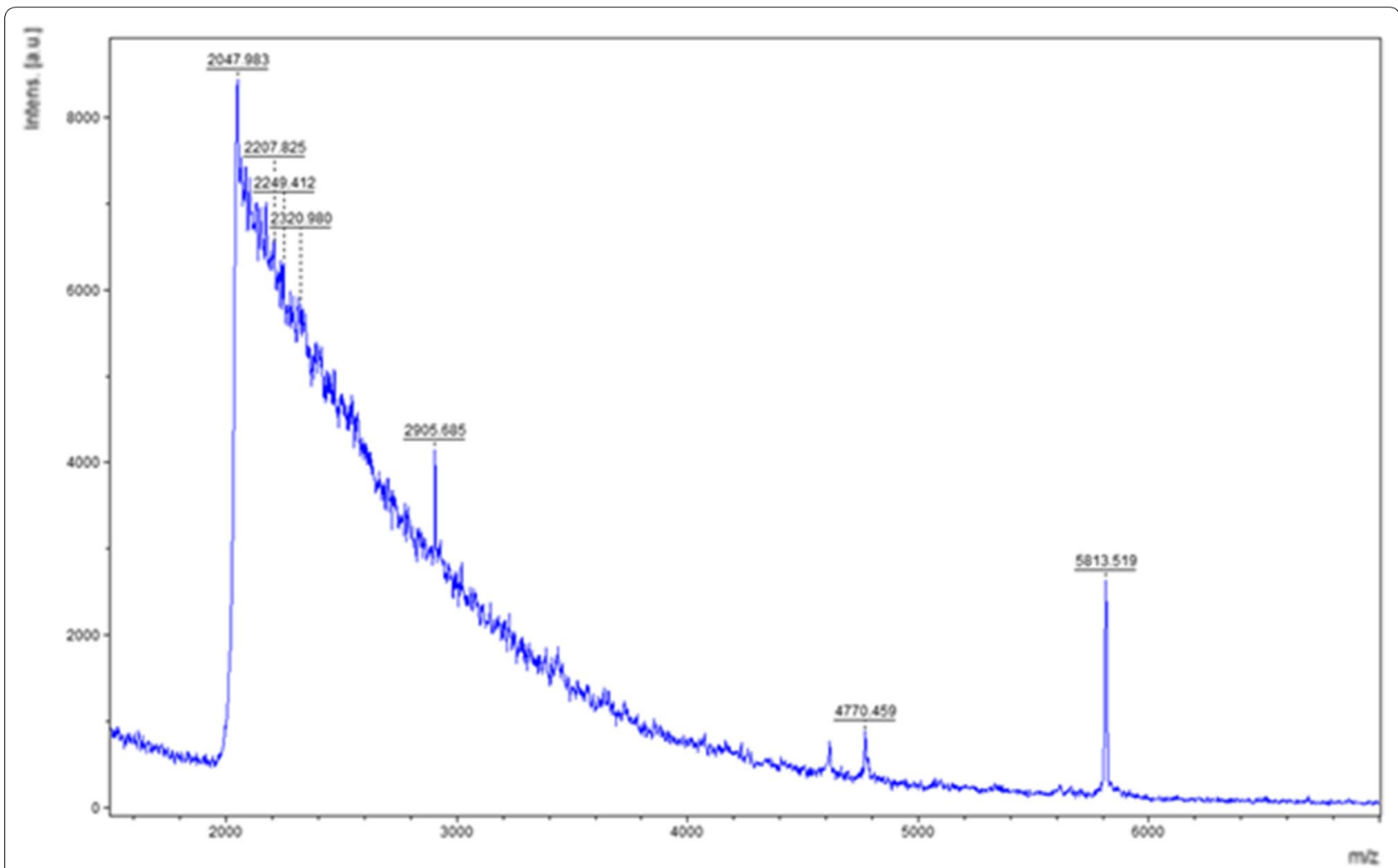

Fig. 2 A MALDI-TOF spectrum illustrating the supernatant sample of crude biosynthesised human insulin, which was induced at 1 mM IPTG

Table 1 The concentrations of human insulin obtained for the IPTG induction calculated based on commercial human insulin

\begin{tabular}{llc}
\hline $\begin{array}{l}\text { IPTG induced } \\
\text { sample }\end{array}$ & $\begin{array}{l}\text { Concentration (mg/L) } \\
\text { (intracellular) }\end{array}$ & $\begin{array}{l}\text { Concentration } \\
\text { (mg/L) (inclusion } \\
\text { body) }\end{array}$ \\
\hline $1 \mathrm{mM}$ & 210.83 & 65.45 \\
$0.5 \mathrm{mM}$ & 393.81 & 64.20 \\
$0.1 \mathrm{mM}$ & 520.92 & 107.82 \\
\hline
\end{tabular}

conditions. Table 1 shows that $0.1 \mathrm{mM}$ IPTG induced the optimum yield for recovering human insulin using $E$. coli BL21 DE3-pET21b-hPin expression system, according to the standard curve using the commercially available standard human insulin (Additional file 1: Figure S4). Most of the induced human insulin was in the intracellular (soluble) fraction, with $520.92 \mathrm{mg} / \mathrm{L}$ of human insulin received in the intracellular fraction for $0.1 \mathrm{mM}$ IPTG

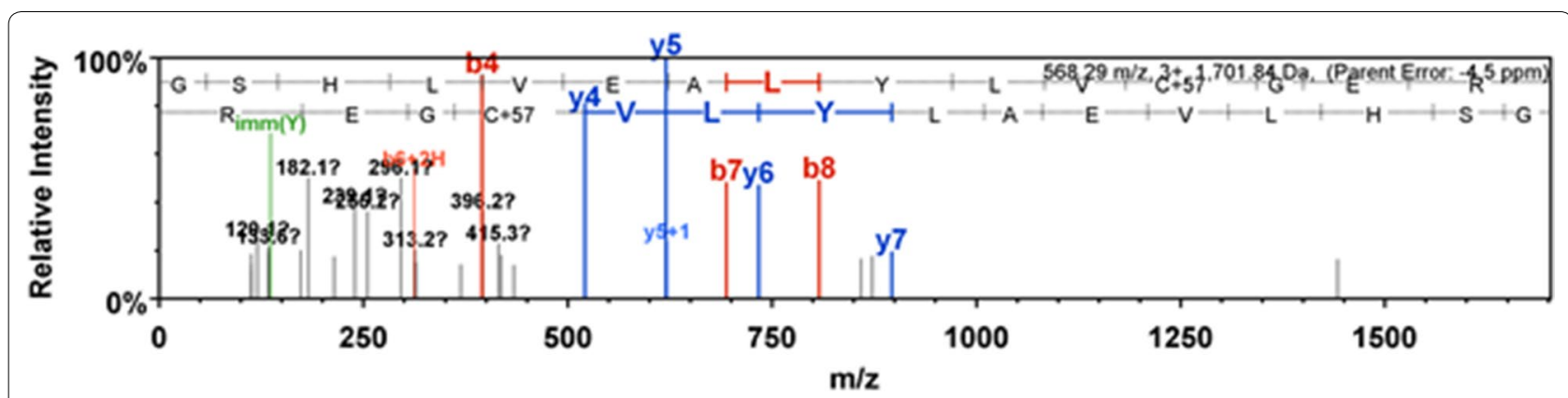

Fig. 3 A peptide spectrum illustrating the protein sequence of crude biosynthesised human insulin, which was a $100 \%$ match to the human insulin sequence derived from the Scaffold 1.4.4 software 
induction; compared to $393.81 \mathrm{mg} / \mathrm{L}$ and $210.83 \mathrm{mg} / \mathrm{L}$ under $0.5 \mathrm{mM}$ and $1.0 \mathrm{mM}$ IPTG, respectively.

\section{Protein sequencing of induced biosynthesised human insulin}

The crude biosynthesised human insulin protein was sequenced. The standard human insulin was set as a positive control. The protein sequencing results confirmed that the biosynthesised protein was human insulin (Fig. 3; Additional file 1: Table S1). After a concatenated database search, the fragmented biosynthesised human insulin peptide sequence was found to have a $100 \%$ similarity match to that of the human insulin sequence from the protein database.

\section{Biological activity of human insulin}

The biological activity was tested using a MTT assay in vitro, using the HepG2 cell line under hyperglycaemic conditions (Fig. 4). In the MTT assay, three concentrations were used of the standard human insulin and crude biosynthesised human insulin: low $(50 \mu \mathrm{g} / \mathrm{mL})$, medium $(100 \mu \mathrm{g} / \mathrm{mL})$ and high $(150 \mu \mathrm{g} / \mathrm{mL})$. The results revealed that, for the low treatment the crude biosynthesised human insulin displayed higher cell viability than the standard human insulin; whereas the medium and high concentrations exhibited similar cell viability to that of the standard human insulin. The results were statistically significant with a calculated probability (p-value) of $<0.0001$.

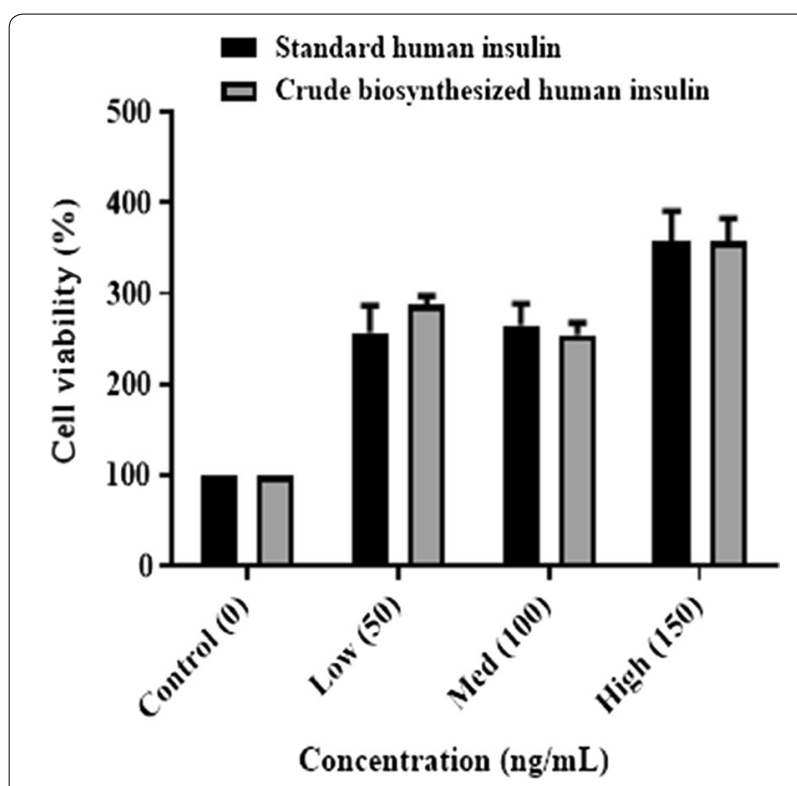

Fig. 4 A graph illustrating the cell viability of HepG2 cells, under hyperglycaemic conditions for standard human insulin and crude biosynthesised human insulin at low $(50 \mathrm{ng} / \mathrm{mL})$, medium (100 ng/ $\mathrm{mL}$ ) and high $(150 \mathrm{ng} / \mathrm{mL}$ ) MTT concentrations ( $\mathrm{p}$-value $<0.0001)$

\section{Discussion}

This study developed a novel and efficient biosynthetic laboratory-scale method of human insulin production using an innovative recombinant cloning strategy, pET21b-hPin vector; and an E. coli BL21 (DE3) expression system was employed using proinsulin (Fig. 2). Insulin can be biosynthesised using two methods. The first method is when the A and B chains of insulin are cloned separately, isolated, and subsequently purified as S-sulfonate derivatives. The chains are thereafter combined to form insulin, which is then purified (Kroef et al. 1989). The second approach involves the use of proinsulin, which is the preferred method of biosynthesising insulin, since a single fermentation is conducted, as opposed to in the first method of insulin production (Kroef et al. 1989). In terms of costs associated with affinity tag removal on a large scale, the current project was based on the biosynthesis and analysis of the untagged form of human insulin (Norouzi et al. 2016; Young et al. 2012).

This study used a novel PCR-based strategy in the cloning of human insulin. The human insulin gene was amplified and confirmed using PCR (Additional file 1: Figure S1). Subsequently, the pET21b-hPin plasmid was transformed into an expression host BL21 (DE3). The production of biosynthesised human insulin was validated using MALDI-TOF-MS, LC-MS, and protein sequencing (Fig. 3). Commercial human insulin was used as a positive control.

Mention is made in the literature of the human insulin protein being expressed at $1 \mathrm{mM}$ IPTG (Redwan et al. 2007). In this study, the human insulin protein was initially induced with $1 \mathrm{mM} \mathrm{IPTG}$ at $37^{\circ} \mathrm{C}$. Thereafter, the optimisation of the expression of human insulin was conducted, where the IPTG concentration was varied. The samples were detected using MALDI-TOF-MS (Fig. 2) and LC-MS (Additional file 1: Figure S3). A standard curve derived from various sample concentrations of standard human insulin was generated using MALDITOF-MS to extrapolate the respective protein concentrations from the biosynthesised human insulin supernatant and pellet fractions. The concentrations of the protein found in the intracellular fractions (soluble fractions) were $520.92 \mathrm{mg} / \mathrm{L}, 393.81 \mathrm{mg} / \mathrm{L}$ and $210.83 \mathrm{mg} / \mathrm{L}$; and in the pellets (inclusion body/insoluble fractions) they were $107.82 \mathrm{mg} / \mathrm{L}, 64.20 \mathrm{mg} / \mathrm{L}$ and $65.45 \mathrm{mg} / \mathrm{L}$ for the respective IPTG concentrations of $0.1 \mathrm{mM}, 0.5 \mathrm{mM}$ and $1 \mathrm{mM}$ (Table 1). The optimum condition for the induction of human insulin was $0.1 \mathrm{mM}$ IPTG.

This study optimised human insulin protein expression, where the human insulin protein was expressed in the soluble (intracellular) fraction resulting in the elimination of the use of chaotropic agents. The use of chaotropic agents, such as urea and guanidine hydrochloride, 
can result in complete secondary structure denaturation (Singh et al. 2015). The use of guanidine hydrochloride and urea to solubilise protein results in a low yield of the bioactive therapeutic protein (Upadhyay et al. 2016). The proinsulin was produced in inclusion bodies at a $10 \%$ level in E. coli with a yield of $1.3 \mathrm{mg} / \mathrm{L}$ of insulin (Redwan et al. 2007). Solubilisation and refolding can often lead to poor recovery of the protein of the desired bioactive protein (Singh et al. 2015). This study had a yield of approximately $520.92(\mathrm{mg} / \mathrm{L})$ of human insulin located in the intracellular (soluble) fraction, which is higher than in previous reports (Redwan et al. 2007).

Researchers have found that protein expression conducted at a high inducer concentration and temperature resulted in the expression of the biosynthesised protein at an increased translational rate and can eventually result in the formation of inclusion bodies (Carrió and Villaverde 2005). The formation of inclusion bodies in bacterial expression hosts such as $E$. coli presents challenges in the recovery process of bioactive proteins (Upadhyay et al. 2016). The extraction of recombinant biosynthesised proteins from inclusion bodies usually results in low yields of the bioactive protein, and this process is laborious (Singh et al. 2015). Inclusion bodies require downstream processing such as isolation from the cell, solubilisation, purification, and refolding of the protein (Redwan et al. 2007; Singh et al. 2015; Zieliński et al. 2019). In this study, the protein was expressed mainly in the soluble fraction; therefore, the inclusion body recovery and renaturation of the protein steps were eliminated, which decreased the expenses associated with these steps. Therefore, the method of human insulin biosynthesis employed in this study is a more efficient process than the current methods (Zieliński et al. 2019).

The proinsulin cloning strategy uses the nucleotide sequence encoding for human proinsulin, which consisted of A, B, and C chains (Chance et al. 1999). In the above strategy, proinsulin was cloned, and the C-peptide was cleaved using Achromobacter lyticus protease, carboxypeptidase B, and trypsin (Baeshen et al. 2014; Mollerup et al. 2009; Morihara et al. 1980). Achromobacter lyticus protease (Morihara et al. 1980) is a lysine-specific enzyme which can enzymatically convert proinsulin to insulin; it has an advantage over trypsin digestion as it avoids non-specific cleavage after the arginine at position B22 (Mollerup et al. 2009). The C-peptide bond was enzymatically cleaved by the utilisation of cyanogen bromide; this was followed by protein folding and the formation of disulphide bonds (Frank and Chance 1983). The enzymes that are normally used in the C-peptide cleavage, such as carboxypeptidase B, are costly (Redwan et al. 2007). This ground-breaking study eliminated the expensive digestion of the $\mathrm{C}$-peptide, which occurred as a result of autocatalytic cleavage (Gooch 2011).

The human insulin that was biosynthesised in this study was detected and verified using MALDI-TOF-MS, LC-MS, and protein sequencing. Standard human insulin served as a positive control for the protein sequencing of human insulin with a $90 \%$ similarity to the human insulin sequence from the protein database (Additional file 1: Figure S5). The crude biosynthesised human insulin protein produced in this study was verified using protein sequencing. After a concatenated peptide database search, the crude biosynthesised human insulin was unequivocally proven to be human insulin with a $100 \%$ similarity (Fig. 3). Therefore, this study successfully biosynthesised and optimised the expression of human insulin in E. coli.

This study employed an in vitro MTT assay to determine the biological activity. The MTT assay is used to measure the viability of metabolically active cells based on their ability to produce reducing equivalents (Carrió and Villaverde 2005; Morihara et al. 1980). The cell uptake of MTT by a protein facilitated mechanism or by endocytosis leads to the reduction of MTT. This yields a purple formazan product, which is impermeable to cell membranes and results in its accumulation within living cells (Hansen and Bross 2010; Maioli et al. 2009; Mosmann 1983). The solubilisation of the cells results in the release of the purple product, which is detected colorimetrically (Maioli et al. 2009). The cells' respiratory chain (Slater et al. 1963) and other electron transport systems (Liu et al. 1997) cause the reduction of MTT. The reduction of MTT by living cells is an indication of mitochondrial activity, which therefore serves as a measure of cell viability (Maioli et al. 2009). Insulin is involved in the regulation of glucose uptake into muscle and fat cells (Drejer 1992). Insulin works within seconds to activate the tyrosine kinase receptor, ion transport systems, and stimulation of glucose (Drejer 1992). Therefore, the glucose utilisation by the HepG2 cells results in an increase of cellular respiration and mitochondrial activity, resulting in an increase in cell viability. The biological activity was tested in this study using a MTT assay in vitro, using a HepG2 cell line with normoglycaemic $(5.5 \mathrm{mM})$ and hyperglycaemic $(25 \mathrm{mM})$ conditions (Chen et al. 2006). The MTT assay exhibited increased cell viability in the hyperglycaemic treatments. There were three treatment concentrations of standard human insulin and crude biosynthesised human insulin: low (50 ng/ $\mathrm{mL})$, medium (100 $\mathrm{ng} / \mathrm{mL})$, and high (150 ng/mL). The analysis was conducted on standard human insulin and biosynthesised human insulin. The standard human insulin served as a positive control. The cell 
viability of the crude biosynthesised human insulin showed $(288.42 \% \pm 9.04 \%) \quad$ low, $\quad(254.57 \% \pm 12.96 \%)$ medium and $(358.70 \% \pm 24.17 \%)$ high concentrations, in comparison to standard human insulin which had $(257.37 \% \pm 29.65 \%)$ low, $(265.23 \% \pm 23.61 \%)$ medium and $(358.07 \% \pm 33.10 \%)$ high concentrations. In the low concentration, the crude biosynthesised human insulin displayed higher cell viability than the standard human insulin; whereas the medium and high concentrations exhibited similar cell viability to that of the standard human insulin. As such, the efficacy was determined to be the same as the standard human insulin. Therefore, we can conclude that the novel method employed in this study is an efficient and effective method of human insulin production.

The biological activity test conducted in this study revealed that the crude biosynthesised human insulin displays similar efficacy to that of the commercially available standard human insulin. This study successfully provided a novel method for the biosynthesis of human insulin since it employed the untagged $\mathrm{pET} 21 \mathrm{~b}$ expression vector in E. coli. The elimination of affinity tags has implications with regards to protein purification, as well as the reduction in downstream processing costs, such as glutathione $S$-transferase and histidine tag removal. In addition, this method also eliminated the tedious protein enzymatic cleavage of the $\mathrm{C}$-peptide, the recovery of human insulin from inclusion bodies, and human insulin renaturation steps; thereby making this process less labour intensive. This study was conducted on a laboratory-scale; however, it has the potential to be up-scaled industrially. Future studies can focus on finding a greener and more affordable purification method for human insulin.

\section{Supplementary information}

Supplementary information accompanies this paper at https://doi. org/10.1186/s13568-020-00969-w.

Additional file 1. Figure S1a. An image depicting a purified PCR product of human proinsulin gene. Lane 1 contains the one $\mathrm{kb}$ molecular weight marker, and lane 2 contains the purified BamHI, and an Xhol ended PCR product of human proinsulin gene (345 bp). b. An image displaying colony PCR products of positive transformants obtained from clones that contain the pET21b-hPin vector. Lane 1 contains the one kb molecular weight marker, and lanes 2-5 contain colony PCR amplicons (345 bp). Figure S2. An image depicting a MALDI-TOF spectrum of standard human insulin as a positive control. Figure S3. A LC-MS chromatogram illustrating 1 mM IPTG induced biosynthesised human insulin sample. Figure S4. A MALDI-TOF standard curve of the human insulin standard at $0 \mathrm{ng}, 10 \mathrm{ng}$, $50 \mathrm{ng}, 100 \mathrm{ng}$, and $1000 \mathrm{ng}$. Figure S5. A peptide spectrum illustrating the protein sequence of standard human insulin, which was $90 \%$ similar to the human insulin sequence derived from Scaffold 1.4.4 software. Table S1. Peptide fragmentation table of crude biosynthesised human insulin, which yielded a $100 \%$ match to human insulin in the protein database.

\section{Abbreviations}

E. coli: Escherichia coli; IU: International units; aa: Amino acid; DNA: Deoxyribonucleic acid; RP-HPLC: Reversed phase-high performance liquid chromatography; PCR: Polymerase chain reaction; USA: United States of America; rpm: Revs per minute; $\mathrm{OD}_{600}$ : Optical density at a wavelength of $600 \mathrm{~nm}$; LB: LuriaBertani; IPTG: Isopropyl $\beta$-D thiogalactoside; kDa: Kilo-Dalton; MALDI-TOF-MS: Matrix-assisted laser desorption ionization-time of flight-mass spectrometry; kV: Kilovolts; Da: Dalton; nm: Nanometres; CHCA or HCCA: Alpha-cyano4-hydroxycinnamic acid; LC-MS: Liquid chromatography-mass spectrometry; CRAP: Contaminant protein database; MTT: 3-(4, 5-Dimethylthiazol-2-yl)-2, 5-diphenyl tetrazolium bromide; HepG2: Hepatocellular carcinoma; PBS: Phosphate-buffered saline; DMSO: Dimethyl sulfoxide; OD: Optical densities; ANOVA: Analysis of variance; p-value: Calculated probability.

\section{Acknowledgements}

This study was made possible through financial support from the University of KwaZulu-Natal, National Research Foundation (NRF) Grant Number: 105216, the Technology Innovation Agency (TIA) of South Africa. We would like to acknowledge the Central Analytical Facility (Stellenbosch University, South Africa) for conducting protein sequencing.

\section{Authors' contributions \\ KG biosynthesised human insulin using recombinant DNA technology, ana- lysed all the experimental data and composed the entire manuscript, includ- ing the supporting information. TD, NSA, and AAC conducted the MTT assay. The rest of the authors are co-supervisors on the project and contributed to the conceptualisation of the idea, funding of the project, and scientific guid- ance. All authors read and approved the final manuscript.}

\section{Availability of data and materials}

The data generated during this study are included in the published article (and its online supplementary file). Additional information regarding the data generated from the current study is available from the corresponding author upon request.

\section{Ethics approval and consent to participate}

This article does not contain any studies with animals performed by any of the authors.

\section{Consent for publication}

Not applicable.

\section{Competing interests}

The authors declare no conflict of interests.

\section{Author details}

${ }^{1}$ Catalysis and Peptide Research Unit (CPRU), School of Health Sciences, University of KwaZulu-Natal, E-block, 6th Floor, Room E1-06-016, Westville Campus, Durban, South Africa. ${ }^{2}$ School of Life Sciences, University of KwaZulu-Natal, Durban, South Africa. ${ }^{3}$ School of Laboratory Medicine and Medical Sciences, College of Health Sciences, University of KwaZulu-Natal, Durban, South Africa. ${ }^{4}$ Department of Chemistry, University of Zululand, Private Bag X1001, Kwadlangezwa 3886, South Africa.

Received: 30 October 2019 Accepted: 5 February 2020

Published online: 10 March 2020

\section{References}

Abdul NS, Nagiah S, Chuturgoon AA (2016) Fusaric acid induces mitochondrial stress in human hepatocellular carcinoma (HepG2) cells. Toxicon 119:336-344

Ahmad B (2004) Review: pharmacology of insulin. Br J Diabetes Vasc Dis 4(1):10-14

Baeshen NA, Baeshen MN, Sheikh A, Bora RS, Ahmed MMM, Ramadan HA, Saini KS, Redwan EM (2014) Cell factories for insulin production. Microb Cell Fact 13(1):1

Banting F, Best C (1922) The internal secretion of the pancreas. J Lab Clin Med 7(5):465-480 
Basu S, Yudkin JS, Kehlenbrink S, Davies JI, Wild SH, Lipska KJ, Sussman JB, Beran D (2019) Estimation of global insulin use for type 2 diabetes, 2018 30: a microsimulation analysis. Lancet Diabetes Endocrinol 7(1):25-33

Beals JM, DeFelippis MR, Kovach PM, Jackson JA (2013) Insulin pharmaceutical biotechnology. Springer, Berlin, pp 255-275

Carrió MM, Villaverde A (2005) Localization of chaperones DnaK and GroEL in bacterial inclusion bodies. J Bacteriol 187(10):3599-3601

Chance RE, Kroeff EP, Hoffmann JA, Frank BH (1981) Chemical, physical, and biologic properties of biosynthetic human insulin. Diabetes Care 4(2):147-154

Chance RE, Glazer NB, Wishner KL (1999) Insulin lispro (humalog) biopharmaceuticals, an industrial perspective. Springer, Berlin, pp 149-171

Chen Q, Xia Y, Qiu Z (2006) Effect of ecdysterone on glucose metabolism in vitro. Life Sci. 2006;78(10):1108-13. https://doi.org/10.1016/j. Ifs.2005.06.031

Drejer K (1992) The bioactivity of insulin analogues from in vitro receptor binding to in vivo glucose uptake. Diabetes Metab Rev 8(3):259-285

Frank B, Chance R (1983) Two routes for producing human insulin utilizing recombinant DNA technology. MMW, Munchener medizinische Wochenschrift. :S14

Gooch JW (2011) Autocatalytic. Encyclopedic dictionary of polymers. pp 876-876. https://doi.org/10.1007/978-1-4419-6247-8_13197

Hansen J, Bross P (2010) A cellular viability assay to monitor drug toxicity protein misfolding and cellular stress in disease and aging. Springer, Berlin, pp 303-311

Helling RB, Goodman HM, Boyer HW (1974) Analysis of endonuclease R. EcoRI fragments of DNA from lambdoid bacteriophages and other viruses by agarose-gel electrophoresis. J Virol 14(5):1235-1244

Inoue H, Nojima H, Okayama H (1990) High efficiency transformation of Escherichia coli with plasmids. Gene 96(1):23-28

Kroef EP, Owens RA, Campbell EL, Johnson RD, Marks HI (1989) Production scale purification of biosynthetic human insulin by reversed-phase highperformance liquid chromatography. J Chromatogr A 461:45-61

Liu Y, Peterson DA, Kimura H, Schubert D (1997) Mechanism of cellular 3-(4, 5-dimethylthiazol-2-yl)-2, 5-diphenyltetrazolium bromide (MTT) reduction. J Neurochem 69(2):581-593

Maioli E, Torricelli C, Fortino V, Carlucci F, Tommassini V, Pacini A (2009) Critical appraisal of the MTT assay in the presence of rottlerin and uncouplers. Biol Proced Online 11(1):227

Maseko SB, Natarajan S, Sharma V, Bhattacharyya N, Govender T, Sayed Y, Maguire GEM, Lin J, Kruger HG (2016) Purification and characterization of naturally occurring HIV-1 (South African subtype C) protease mutants from inclusion bodies. Protein Expr Purif 122:90-96. https://doi. org/10.1016/j.pep.2016.02.013

Mollerup I, Jensen SW, Larsen P, Schou O, Snel L, Flickinger MC (2009) Insulin purification encyclopedia of industrial biotechnology. John Wiley \& Sons Inc, New York
Morihara K, Oka T, Tsuzuki H, Tochino Y, Kanaya T (1980) Achromobacter protease l-catalyzed conversion of porcine insulin into human insulin. Biochem Biophys Res Commun 92(2):396-402

Mosmann T (1983) Rapid colorimetric assay for cellular growth and survival: application to proliferation and cytotoxicity assays. J Immunol Methods 65(1-2):55-63

Norouzi R, Hojati Z, Badr Z (2016) Overview of the recombinant proteins purification by affinity tags and tags exploit systems. J Fundam Appl Sci 8(3):90-104

Redwan ERM, Matar SM, El-Aziz GA, Serour EA (2007) Synthesis of the human insulin gene: protein expression, scaling up and bioactivity. Prep Biochem Biotechnol 38(1):24-39

Singh A, Upadhyay V, Upadhyay AK, Singh SM, Panda AK (2015) Protein recovery from inclusion bodies of Escherichia coli using mild solubilization process. Microb Cell Fact 14(1):41

Slater T, Sawyer B, Sträuli U (1963) Studies on succinate-tetrazolium reductase systems: III. Points of coupling of four different tetrazolium salts III. Points of coupling of four different tetrazolium salts. Biochim Biophys Acta 77:383-393

Upadhyay V, Singh A, Jha D, Singh A, Panda AK (2016) Recovery of bioactive protein from bacterial inclusion bodies using trifluoroethanol as solubilization agent. Microb Cell Fact 15(1):100

Vajo Z, Fawcett J, Duckworth WC (2001) Recombinant DNA technology in the treatment of diabetes: insulin analogs. Endocr Rev 22(5):706-717

Voet D, Voet JG (2011) Biochemistry, 4th edn. John Wiley \& Sons Inc., New York pp 492-496

Volontè F, Piubelli L, Pollegioni L (2011) Optimizing HIV-1 protease production in Escherichia coli as fusion protein. Microb Cell Fact 10(1):53

Walsh G (2005) Therapeutic insulins and their large-scale manufacture. Appl Microbiol Biotechnol 67(2):151-159

Young CL, Britton ZT, Robinson AS (2012) Recombinant protein expression and purification: a comprehensive review of affinity tags and microbial applications. Biotechnol J 7(5):620-634

Zieliński M, Romanik-Chruścielewska A, Mikiewicz D, Łukasiewicz N, Sokołowska I, Antosik J, Sobolewska-Ruta A, Bierczyńska-Krzysik A, Zaleski P, Płucienniczak A (2019) Expression and purification of recombinant human insulin from E. coli 20 strain. Protein Expr Purif 157:63-69

\section{Publisher's Note}

Springer Nature remains neutral with regard to jurisdictional claims in published maps and institutional affiliations.

\section{Submit your manuscript to a SpringerOpen ${ }^{\circ}$ journal and benefit from:}

- Convenient online submission

- Rigorous peer review

- Open access: articles freely available online

- High visibility within the field

Retaining the copyright to your article

Submit your next manuscript at springeropen.com 